\title{
Utilization of Wastewater from Vannamei Shrimp Pond for Rearing Milkfish in Keburuhan Coast Purworejo Sub-District
}

\author{
Djumanto $^{*}$, Ustadi, Rustadi and Bambang Triyatmo \\ Department of Fisheries, Gadjah Mada University \\ Email: lely4192@yahoo.com ${ }^{*}$, ustadi@ugm.ac.id, rustadi@ugm.ac.id,btriyatmo@yahoo.com
}

Received: 23 March 2018; Accepted: 26 June 2018

\begin{abstract}
Djumanto, Ustadi, Rustadi and Bambang Triyatmo. 2018. Utilization of Wastewater from Vannamei Shrimp Pond for Rearing Milkfish in Keburuhan Coast Purworejo Sub-District. Aquacultura Indonesiana, 19 (1): 38-46. Brackish water vannamei shrimp in the village of Keburuhan, Ngombol District of Purworejo Regency is one of the shrimp aquaculture activities developed since 2010. Shrimp farming enteprises is done by local communities which use the sandy soil coated plastic sheet with an area of $1000-4500 \mathrm{~m}^{2}$. There is a positive impact by increasing the income and welfare of farmers, but give negative effects in decline of surrounding pond environment. The shrimp farmers mostly disposed of wastewater directly into the sewers or the surrounding area. The wastewater of vannamei shrimp culture contains of uneaten feed and plankton that can be utilized to grow milkfish. The aim of this study was to determine the growth and feeding preferences for milkfish culture in wastewater reservoir of vannamei culture. The study was conducted from January to April 2017 by rearing of milkfish in earthen ponds of shrimp culture in wastewater reservoir. Wastes consist of feces and uneaten feed during shrimp rearing were siphoned and flowed into ponds wastewater reservoir. Milkfish juvenile with body length ranges from 9.3 to $9.7 \mathrm{~cm}$ and weight ranges from 3.4 to $6.9 \mathrm{~g}$ was introduced into three earthen ponds of $600 \mathrm{~m}^{2}$ each, with density of 6 individual $/ \mathrm{m}^{2}$ in triplicate for 70 days. During the study, milkfish juvenile were not fed, but obtained wastewater from shrimp culture ponds. The wastewater from the shrimp ponds was siphoned and piped into a waste reservoir ponds every 3 days until shrimp harvesting. Fish samples of each pond as much as 40 individuals were taken biweekly and then measured the length and weight. Fish stomach was dissected and then digestive tract was taken to observe the species of plankton consumed. The results showed that milkfish could grow well in wastewater reservoir of shrimp culture. The average daily growth rate of length and weight of milkfish reached approximately $0.11 \mathrm{~cm} /$ day and $0.34 \mathrm{~g} /$ day, respectively. The length weight relationship of milkfish showed allometric growth pattern. The food type found in the intestinal was dominated by phytoplankton. Feed was dominated by genera of phytoplankton, which reach more than 99\%. The most dominant of phytoplankton were Scenedesmus sp. (34.7\%), then Crucigenia sp. (20.1\%), followed by Cyclotella sp. (14.6\%), and Clamydomonas sp. (7.5\%) next Microcystis sp. (6.7\%), while the other genera less than $4.2 \%$. Further research is needed to determine the optimum density of milkfish to utilize wastewater of shrimp culture.
\end{abstract}

Keywords: Growth; Milkfish; Sandy soil; Vannamei; Waste

\section{Introduction}

The vannamei shrimp (Litopenaeus vannamei) is brackish species that now under intensive culture proliferated rapidly in southern coast of Keburuhan Village, and to be quite promising sector to the local community. Shrimp culture in the coastal sandy soil area of Keburuhan village has been growing rapidly since 2014 (Djumanto et al., 2016), due the technical development of using the plastic sheet to cover the sandy soil and watered the pond pumped by machine. Pond bottom was made slope toward outlet or central concave part to collect waste. Uneaten food and shrimp feces become waste that settles in the bottom of the pond. Solid and liquid waste was siphoned off using pumps and flowed directly to the surrounding area. Shrimp culture ponds generally have no sewage drainage or wastewater reservoir. Because of the rapid growth of shrimp farming, large amounts of uneaten food and shrimp feces have been dispersed outside the ponds farms. Subsequently, these particulate organic wastes have accumulated become pollutants on surface water and ground water. When the accumulation of wastes exceeds the assimilative capacity of the water body, negative effects on the environment can be manifested in a wide variety of ways (Srithongouthai and Tada, 2017).

The increasing number of shrimp farming ponds and shrimp culture density in vannamei shrimp culture production can lead to increase the demand of shrimp feeds, and as a result cause to 
accumulation of organic matter in surrounding environment. This accumulation can lead to reduce the water quality due to high inorganic nitrogen compound contents. Shrimp feed accounts for more than $57 \%$ of the total cost in shrimp culture industry (Triyatmo, 2017), as the costs of major feed ingredients: fish meal and cereal grains (i.e. soybean, rice bran, wheat, corn, etc.) are affected by climate, weather conditions, global economic growth and fuel costs. Furthermore, the expansion of intensive shrimp culture has raised environmental concerns due to intensive nutrient accumulation in culture systems and lack of effective waste treatments. The nutrients and organic matter may potentially result in low dissolved oxygen (DO), hypernitrification and eutrophication, as well as sedimentation in receiving waters. In addition to environmental issues, the discharge of untreated pond effluent represents an economic loss of costly nutrients, thereby reducing farm profitability (Yuan et al., 2010).

Utilization of shrimp aquaculture waste to increase production can be done by polyculture in shrimp pond, and also fish culture at wastewater reservoir (Stickney et al.. 1979). Shrimp polyculture is an old practice and might have evolved from early extensive shrimp systems in which fish species such as milkfish (Chanos chanos) were incidentally or intentionally introduced and harvested as extra yield to shrimp (Jhingran, 1982). The practice of polyculture shrimp with other species such as milkfish were done with the purpose of increasing overall production and controlling water quality (Yuan et al., 2010). In Keburuhan Village, some shrimp farmers introduce milkfish in intensive vannamei shrimp culture to overcome with abundant of phytoplankton populations and earn additional income.

The vannamei shrimp pond waste still contains many nutrients, and mainly consists of metabolism waste, uneaten feeds, feces, plankton, dead shrimp, skin shrimp and other organic matters (Triyatmo, 2017). So the wastes are very beneficial as feed source for fishes in public waters as well as those fishes culture in ponds. However the utilization of wastewater from vannamei shrimp farming for fish farming or other aquatic plants has not been done because of the available land is very limited, requires additional construction costs and knowledge for fish culture technology is limited. There is a need to develop culture technology and intensive culture systems with increased waste assimilating capacity to transfer the excessive nutrients into harvestable aquatic products and to avoid uncontrolled effluent discharge. Milkfish is the most widely cultured fish due to their general hardiness, tolerance to wide range of environmental conditions, adaptation to both fresh and brackish water environment, resistance to diseases, ability to efficiently convert organic and domestic wastes into high quality protein, amenability to handling and captivity, and tasty flavor, ease of breeding, rapid growth (Rao and Sivani, 1996). They have proven to be ideal species for monoculture and polyculture (Yakupitigage et al., 1991) and also for utilization of waste from intensive shrimp culture. Milkfish is domesticated finfish species that feed on natural foods of low trophic level, such as detritus and plankton, and they can grow in wide range of salinity (Djumanto et al., 2017) so they appear to be the most appropriate choice for utilization of waste from intensive white shrimp aquaculture system.

In addition, the use of shrimp culture wastes for fish culture would be a more sustainable strategy to reactive local fish culture industry which once prosperous the Village of Keburuhan. The purpose of this research was to know the growth and feeding preferences of milkfish which was reared in wastewater reservoir from intensive culture of white shrimp.

\section{Materials and Methods}

The study was conducted at a shrimp farm collaboration research located in south coast of Keburuhan Village of Purworejo sub-district. The farm operated ponds for shrimp growing and shrimp waste reservoir each. The shrimp pond size was approximately 0.2 ha $\left(60 \times 30 \mathrm{~m}^{2}\right)$ and $1.0 \mathrm{~m}$ deep. Shallow wells as the source of ponds water was sucked up using water pump, and then flown directly to the pond. Well was made by drilling a sandy soil around the pond using high pressure water resulted from machine pump to find water. Subsequently water pipes were inserted the hole until approximately 20 meters depth, and then water was absorbed using machine pump. Salinity of shallow well waters at a depth of $20 \mathrm{~m}$ about 10 ppt. In preparation of shrimp ponds, pond was flooded with well water until $100 \mathrm{~cm}$ deep, stocked with lime and fertilizer to grow plankton as a natural food source of shrimp and to maintain oxygen stability. The scheme for shrimp waste siphoned into reservoir pond for milkfish cultivation is presented in Figure 1. 


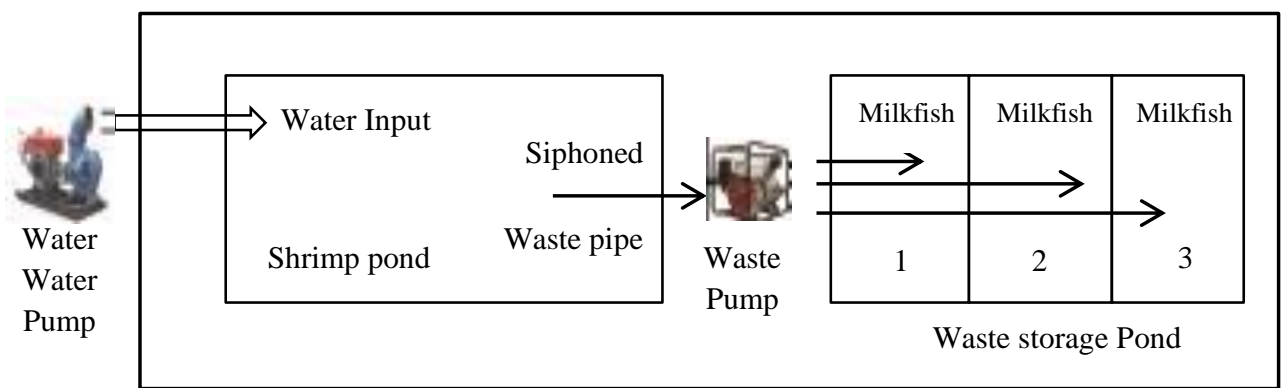

Figure 1. Schematic diagram of shrimp ponds culture and wastewater reservoir for milkfish cultivation. Wastewater of shrimp pond culture that settle down on the bottom was siphoned and flowed into each milkfish ponds

The shrimp larvae (PL 12) were stocked with a density of 50 individual $/ \mathrm{m}^{2}$, fed the smallest grain pellet and feed grain size increased with age. The paddlewheel was operated at night to increase dissolved oxygen content and distribute the nutrients throughout the pond. Solid waste, feed residue, feces and debris settling at the bottom were cleaned by siphon pump. Wastes were siphoned starting on the shrimps 4 weeks old and so on done every 3 days. Waste was sucked out using water pump machine and flowed into a pond waste reservoir. Well water was added to the shrimp pond to maintain the pond water level. The shrimp reared for 70 days and produce nearly 1.5 tons of shrimp per cycle in one pond.

Juvenile of milkfish was obtained from Fish Seed Center (BBI) in Sundak, Gunungkidul Regency. The juvenile with a length of 5-8 cm and a weight of 3-5 g were stocked in $600 \mathrm{~m}^{2}$ waste disposal earthen pond of shrimp culture at density of 6 individuals $/ \mathrm{m}^{2}$ in triplicate for 70 days. During the study, juvenile milkfish were not fed, but obtained wastewater from shrimp culture ponds. The waste from the shrimp ponds was siphoned and piped into waste reservoir ponds every 3 days until shrimp harvesting.

\section{Data collection}

Samples of juvenile milkfish in each experimental pond were caught using cast net with diameter $4 \mathrm{~m}$ and mesh size $0.5 \mathrm{~cm}$, as a random sample of 30-40 individual fish from each pond biweekly. For each individual fish, total length (L) was measured to the nearest $0.1 \mathrm{~cm}$ and whole body weight $(\mathrm{W})$ was recorded to the nearest $0.01 \mathrm{~g}$. The milkfish length was measured using scale boards and weighted with a digital balance individually.

Water sample from each ponds were collected biweekly to measure important parameter. Temperature, dissolved oxygen (DO) concentrations, salinity and $\mathrm{pH}$ were recorded using water quality checker (YSI $556 \mathrm{MP}$ ) at mid depth of each pond, measured in the morning (09.00-10.00 $\mathrm{AM})$ at the time of fish sampling. The total content of $\mathrm{N}$ and total $\mathrm{P}$ were measured 3 times at the weeks 2, 6 and 10, in ponds 1 and 2. Plankton samples were collected from water pond and milkfish intestine at the week $6^{\text {th }}$ of study. Plankton samples were collected $30 \mathrm{~L}$ of water from each pond using basket, then filtered with plankton net mesh size $80 \mu \mathrm{m}$. Plankton concentration were immediately preserved in $4 \%$ formalin for quantitative analysis using a sedge wick-rafter counting cell following direct census method (Suthers and Rissik, 2008).

\section{Data Analysis}

\section{Length weight relationship}

Length weight relationship was calculated from the data collected from the fish sample biweekly. The mathematical relationship between length and weight was calculated using the formula (Biswas, 1992):

$$
W=a L^{b}
$$

where $a$ is the proportionality constant and $b$ is isometric exponent.

Statistical significance of the isometric exponent (b) was analyzed with a function (Ricker, 1973) based on the t-test:

$$
\mathrm{t}=\frac{\mathrm{sd}(\mathrm{x})}{\mathrm{sd}(\mathrm{y})} \frac{|\mathrm{b}-3|}{\sqrt{1-\mathrm{r}^{2}}} \sqrt{\mathrm{n}-2}
$$

where $\mathrm{t}$ is the student statistic; sd $(x)$ and $(y)$ are the standard deviation of $\log L$ and $W$ values; $r^{2}$ is the potential fit determination coefficient; $n$ is the number of specimens recorded.

\section{Growth of Length and Weight}

The average length and weight of milkfish on each sampling was calculated by the following method:

$$
L t=\Sigma L i / n \text { and } W t=\sum W i / n
$$


where $L t$ or $W t$ is average length $(\mathrm{cm})$ or Weight $(\mathrm{g})$, respectively, of fish at age $\mathrm{t}$ (sampling time), $L i$; Wi is length or weight of fish $\mathrm{i}$ at sampling $\mathrm{t} ; n$ is number of fish measured

\section{Daily Growth Rate}

Daily growth rate of milkfish was calculated using a formula:

$$
G=(W T-W 0) / T
$$

where $\mathrm{G}$ is Daily Growth Rate (g/day); W0 is Weight of milkfish at initial day of research $(\mathrm{g})$; $\mathrm{Wt}$ is Weight of milkfish at the latest day of research $(\mathrm{g})$.

\section{Results}

\section{Length weight relationship}

The length weight relationship of milkfish exhibited curvilinear growth pattern (Figure 2). When the parameter $b$ is equal to 3, growth is called isometric and when it is greater or lesser than 3 , it is allometric. Because the slope value of fish obtained in the pond 1 was $b=2.7041$, pond 2 was $b=2.8786$ and pond 3 was $b=$ 3.2917 , hence they were significantly different from 3 based on $\mathrm{t}$ (pond $1 \mathrm{t}=11.157$, pond $2 \mathrm{t}$
$=10.024$, pond $3 \mathrm{t}=9.138 ; \mathrm{P}<0.5)$, the growth of milkfish was allometric. The value of $b$ for milkfish reared in pond 1 and 2 was comparatively higher than the pond 3 .

\section{Growth performance}

Initially the length and weight of juvenile milkfish were found in certain equal range of size 9.3-9.7 $\mathrm{cm}$ and 3.4-6.9 g, respectively. Figure 3 showed that juvenile milkfish culture over 10 weeks in pond waste water reservoir of shrimp culture could grow very well. The average length of milkfish at each sampling showed increase smoothly. The average length initially was 9.3$9.7 \mathrm{~cm}$ increased to $10.4-10.7 \mathrm{~cm}$ at the end of the 2 nd weeks, next at the end of the 4 th week the average length was 12.5-12.9 increased to $14.1-15.4 \mathrm{~cm}$ at the end of 6th week, and after that the average length increased to 8 to 15.4$16.3 \mathrm{~cm}$, and finally the average length at the end of the research was $17.5-18.2 \mathrm{~cm}$. The length increments average was relatively constant since in the early of the study to the end of the research. Stable grow to the ponds that receive shrimp culture waste indicated that milkfish was able to accept feed waste of shrimp culture.

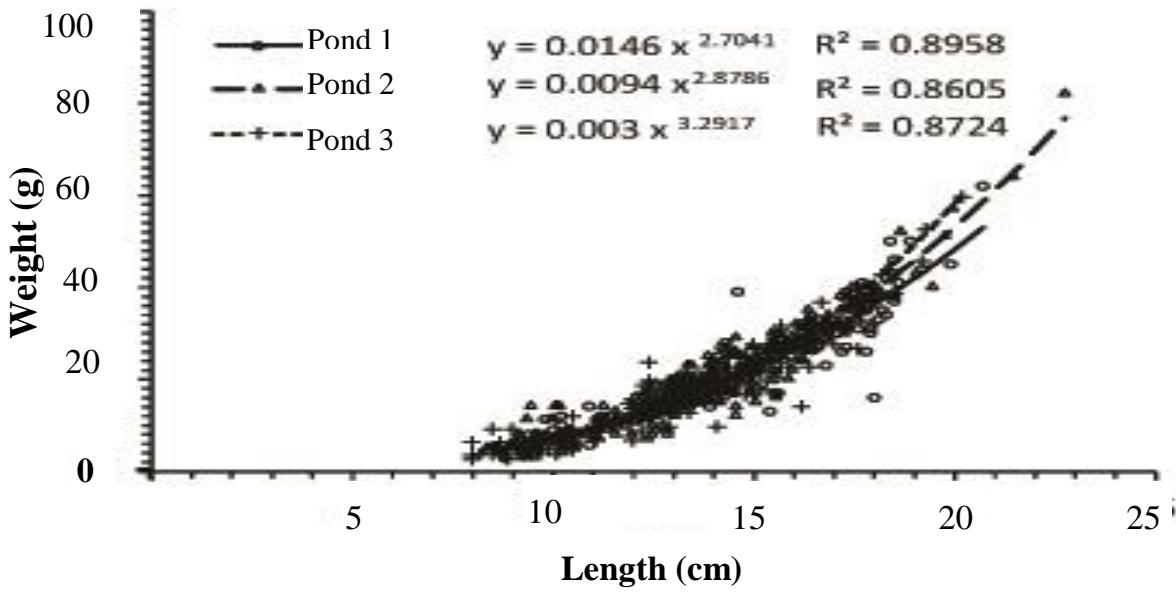

Figure 2. Length weight relationship of milkfish grown in pond wastewater reservoir of shrimp culture.
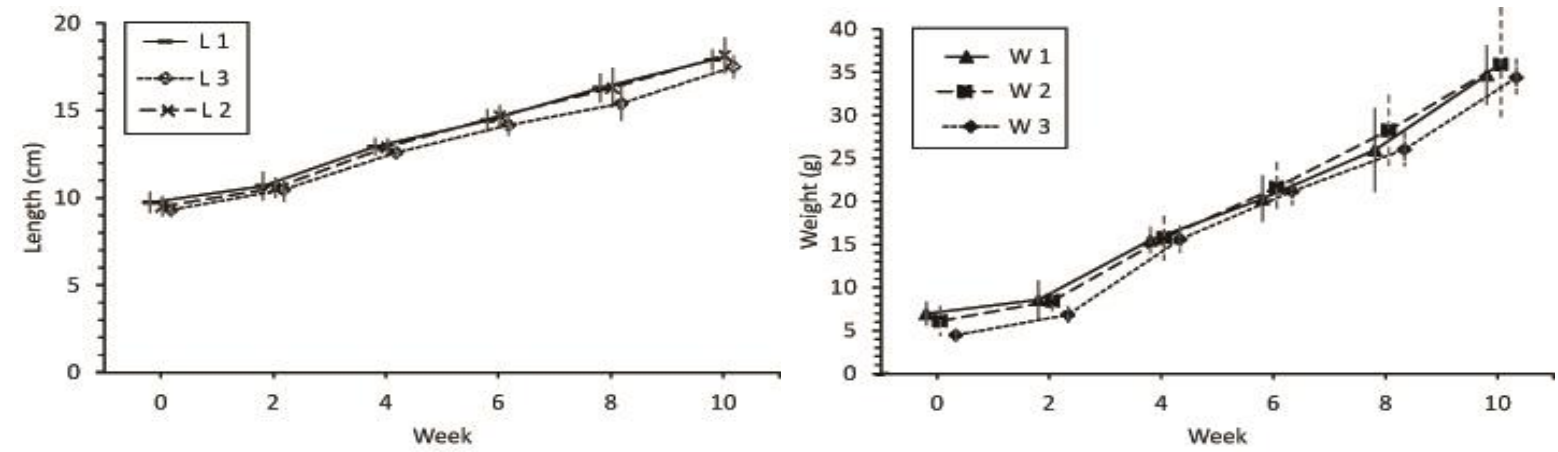

Figure 3. The growth of length (cm, left) and weight (g, right) of milkfish culture in ponds wastewater reservoir of shrimp farming, the bar line is the standard deviation. 
The average weight of milkfish in each observation also increased. The average weight at the beginning of sampling was 4.4-7.7 $\mathrm{g}$ increased to $6.8-8.6 \mathrm{~g}$ at the end of $2^{\text {nd }}$ week. Then at the end of week $4^{\text {th }}$ the weight was 15.5-15.9 then increased to 20.3-21.8 $\mathrm{g}$ at the end of week $6^{\text {th }}$. Next at the end of week $8^{\text {th }}$ the weight of milkfish was 26.0-28.5, and the weight at the end of the study was 34.3-36.1 g. The weight gain in week $0-2$ was relatively slow then increased rapidly in the week $4^{\text {th }}$ to the end of the study. The relatively slow weight gain in the early weeks might cause by the low availability of natural feed, this due to waste from the shrimp culture was siphoned start at week $2^{\text {nd }}$ of the research or the week $4^{\text {th }}$ of the shrimp culture. Hence very rapid weight growth occurred from week 4 to the end of the study.

\section{Daily Growth Rate}

Growth of milkfish indicated that the fish was able to adapt to the new environment and take advantage of available food resources. The average daily growth rate of length and weight of milkfish reached approximately $0.11 \mathrm{~cm} /$ day and $0.34 \mathrm{~g} / \mathrm{day}$. In the first biweekly of culture, the length and weight growth rate attained 0.05 $\mathrm{cm} /$ day and $0.15 \mathrm{~g} /$ day, respectively. However, in the following biweekly the length growth rate increased almost three fold $(0.13 \mathrm{~cm} /$ day $)$ and the weight growth rate also increase three fold $(0.45$ $\mathrm{g} /$ day). The lowest length growth rate was 0.04 $\mathrm{cm} /$ day, while the highest was $0.21 \mathrm{~cm} /$ day. The lowest weight growth rate was $0.11 \mathrm{~g} /$ day, while the highest was $0.59 \mathrm{~g} / \mathrm{day}$. As overall, the average

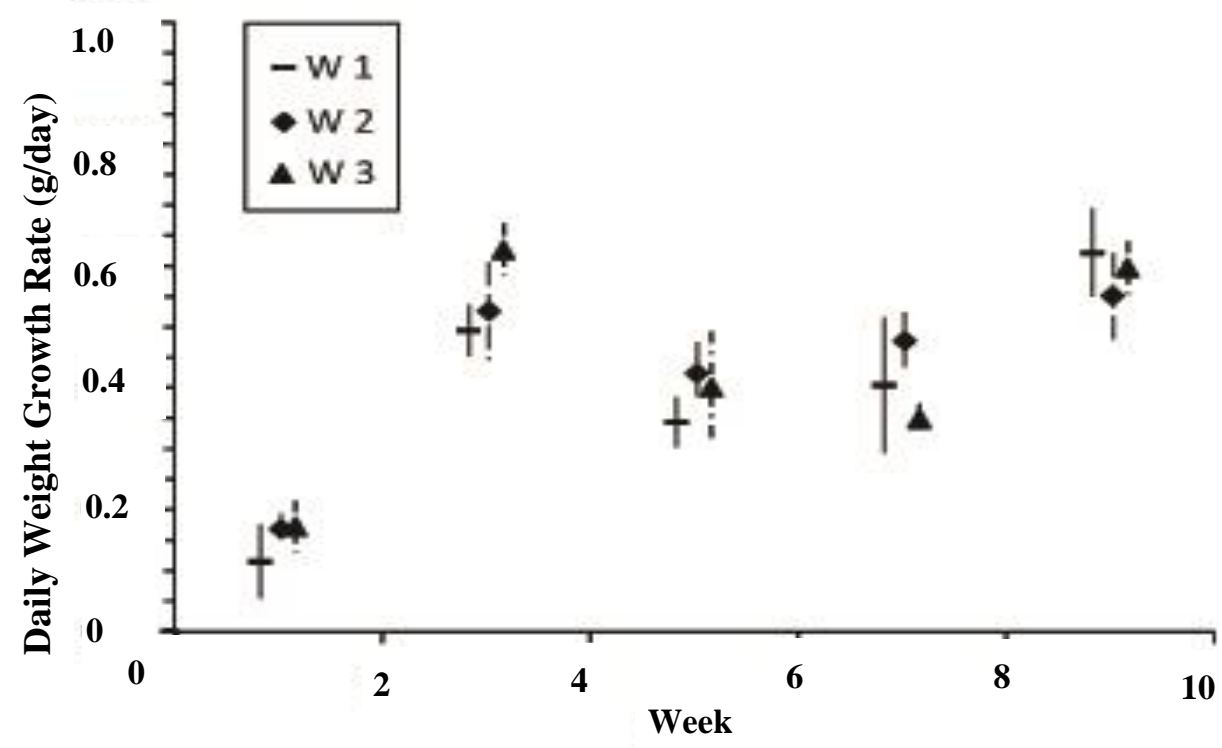

Figure 4. Daily length growth rate $(\mathrm{cm} / \mathrm{day}$, left) and weight (g/day, right) of milkfish culture in wastewater reservoir of shrimp farming, the bar line is the standard deviation.

daily growth rate of length and weight of milkfish reached approximately $0.11 \mathrm{~cm} /$ day and 0.34 $\mathrm{g} /$ day, respectively. Average daily growth rate of length and weight is shown in Figure 4.

Growth increment for length and weight showed increase drastically from the first biweekly to the second biweekly, then a slightly decrease in the third biweekly, and next gradually increase in the fourth biweekly until the end of culture period. It was probably caused by the milkfish pond received culture waste from shrimp farming starting the second weeks after milkfish stocking. During the first biweekly, the milkfish fed the natural food available in the pond, then they use the culture waste from shrimp pond.

\section{Water quality parameters}

The water quality parameters of the ponds were presented in Table 1. Mean values and temporal variation were similar for all ponds occurred in temperature, DO, and $\mathrm{pH}$. The recorded parameters were within optimum ranges for milkfish culture. Salinity for pond 1, 2 and 3 ranged from 2.2 to $5.2 \mathrm{ppt}$, from 2.0 to $5.1 \mathrm{ppt}$, and from 2.1 to $5.1 \mathrm{ppt}$, respectively. However, dissolved oxygen concentration showed low level throughout the culture period of milkfish. Dissolve oxygen concentration on pond 1,2 and 3 ranged 2.3 to $5.6 \mathrm{ppm}$, from 2.1 to $5.3 \mathrm{ppm}$, and from to $4.1 \mathrm{ppm}$, respectively. This was probably due of oxygen by organic matera the waste. In general, temperature and DO fluctuated within suitable ranges for milkfish growth. 
Table1. Water quality parameter in the experimental ponds

\begin{tabular}{|c|c|c|c|c|c|}
\hline Time & Parameter & Pond 1 & Pond 2 & Pond 3 & Shrimp pond \\
\hline \multirow[t]{6}{*}{ Week 0} & Temp $\left({ }^{\circ} \mathrm{C}\right)$ & 29.2 & 29.6 & 29.7 & 29.6 \\
\hline & Sal (ppt) & 2.5 & 2.4 & 2.3 & 2.4 \\
\hline & $\mathrm{DO}(\mathrm{ppm})$ & 4.6 & 2.8 & 2.8 & 2.8 \\
\hline & $\mathrm{pH}$ & 6.9 & 6.8 & 6.7 & 6.8 \\
\hline & Total N (ppm) & 0.276 & 0.277 & $\mathrm{x}$ & 0.26 \\
\hline & Total P (ppm) & 0.0346 & 0.018 & $\mathrm{x}$ & 0.053 \\
\hline \multirow[t]{4}{*}{ Week 2} & Temp $\left({ }^{\circ} \mathrm{C}\right)$ & 29.2 & 29.7 & 29.9 & 30.9 \\
\hline & Sal (ppt) & 2.8 & 2.7 & 2.6 & 5.8 \\
\hline & $\mathrm{DO}(\mathrm{ppm})$ & 3.9 & 3.0 & 3.2 & 3.7 \\
\hline & $\mathrm{pH}$ & 6.9 & 7.1 & 7.0 & 7.5 \\
\hline \multirow[t]{4}{*}{ Week 4} & Temp $\left({ }^{\circ} \mathrm{C}\right)$ & 29.2 & 29.4 & 29.5 & 31.3 \\
\hline & Sal (ppt) & 2.2 & 2.0 & 2.1 & 5.3 \\
\hline & $\mathrm{DO}(\mathrm{ppm})$ & 2.3 & 2.1 & 1.9 & 3.6 \\
\hline & $\mathrm{pH}$ & 7.1 & 7.0 & 7.1 & 8.1 \\
\hline \multirow[t]{6}{*}{ Week 6} & Temp $\left({ }^{\circ} \mathrm{C}\right)$ & 34.9 & 35.5 & 34.5 & 32.7 \\
\hline & Sal (ppt) & 2.8 & 2.7 & 3 & 5.9 \\
\hline & $\mathrm{DO}(\mathrm{ppm})$ & 11.2 & 11.1 & 12 & 11.9 \\
\hline & $\mathrm{pH}$ & 8.2 & 8.5 & 8.5 & 8.3 \\
\hline & Total N (ppm) & 1.565 & 0.114 & $\mathrm{x}$ & 2.57 \\
\hline & Total P (ppm) & 0.423 & 0.422 & $\mathrm{x}$ & 0.422 \\
\hline \multirow[t]{4}{*}{ Week 8} & Temp $\left({ }^{\circ} \mathrm{C}\right)$ & 29.9 & 29.4 & 30.1 & 30.1 \\
\hline & Sal (ppt) & 5 & 4.2 & 3.7 & 7.6 \\
\hline & $\mathrm{DO}(\mathrm{ppm})$ & 2.9 & 2.7 & 3.5 & 5.4 \\
\hline & $\mathrm{pH}$ & 7 & 6.8 & 7.2 & 7.5 \\
\hline \multirow[t]{6}{*}{ Week 10} & Temp $\left({ }^{\circ} \mathrm{C}\right)$ & 29.6 & 29.5 & 30.1 & 30.1 \\
\hline & Sal (ppt) & 5.2 & 5.1 & 5.1 & 7.5 \\
\hline & $\mathrm{DO}(\mathrm{ppm})$ & 5.6 & 5.3 & 4.1 & 4.2 \\
\hline & $\mathrm{pH}$ & 6.4 & 6.9 & 7.1 & 7.8 \\
\hline & Total N (ppm) & 0.362 & 0.246 & $\mathrm{x}$ & 2.58 \\
\hline & Total P (ppm) & 0.416 & 0.439 & $\mathrm{x}$ & 0.42 \\
\hline
\end{tabular}

The mean total concentration of nitrogen in milkfish pond and shrimp ponds at week $2^{\text {nd }}$ was relatively the same, which was $0.27 \mathrm{ppm}$ and 0.26 $\mathrm{ppm}$, respectively. At week $6^{\text {th }}$, the average concentration of total nitrogen in milkfish ponds ranged from 0.11-1.55 $\mathrm{ppm}$, whereas in shrimp ponds attained $2.57 \mathrm{ppm}$. The total concentration of nitrogen in milkfish ponds at the week $10^{\text {th }}$ was more varied. The average total nitrogen concentration in milkfish ponds ranged 2.4-3.6 ppm, whereas in shrimp ponds reach $2.58 \mathrm{ppm}$. The total concentration of nitrogen in milkfish ponds at the week $6^{\text {th }}$ reached almost half of the total nitrogen concentration in shrimp farms. It showed the total nitrogen in milkfish ponds used by phytoplankton for its growth. Contrasting conditions occurred at week $10^{\text {th }}$, where the total concentration of nitrogen in the milkfish pond reached almost twice. This was probably caused by two factors namely, firstly the density of phytoplankton in the milkfish pond was very little due to predation, and secondly caused the supply of waste quantity from shrimp ponds was increasing.
The total phosphorus concentration was relatively different from that total nitrogen. In the first week, the total concentration of phosphorus in milkfish ponds ranged from $0.018-0.035 \mathrm{ppm}$, whereas in shrimp pond was almost doubling, that was $0.053 \mathrm{ppm}$. At the next biweekly, i.e. week $6^{\text {th }}$ and $10^{\text {th }}$, the total phosphor concentration in the waters of milkfish and shrimp ponds was relatively the same, i.e. nearly was $0.42 \mathrm{ppm}$ among ponds. It shows that the total phosphor in pond waters in the first week was utilized by phytoplankton for its growth. Furthermore, because the density of phytoplankton decreased, while the concentration of phosphate in shrimp waste increased steadily, the phosphate in the milkfish concentration was proportional.

\section{Plankton}

Phytoplankton and zooplankton concentration in each pond and fish intestine was presented in Table 2. The average composition of plankton, as overall the type of plankton found in the pond waters as much as 7 genera zooplankton 
and 18 genera of phytoplankton. The type of plankton found in the pond waters as much as 7 genera phytoplankton and 6 genera zooplankton, while the type of plankton found in milkfish intestine as much as 3 genera zooplankton and 16 genera phytoplankton. In milkfish intestine content, the type of phytoplankton was more common than zooplankton. Milkfish was preferring phytoplankton as the main feeding menu, while zooplankton was as an additional feed menu.

Table 2. The density of Phytoplankton (cell/L) and zooplankton (Ind./L) in each ponds and the composition in intestine of milkfish

\begin{tabular}{|c|c|c|c|c|c|c|c|c|c|c|c|c|}
\hline \multirow{3}{*}{$\begin{array}{c}\text { Zooplankton } \\
\text { (Ind/L) }\end{array}$} & \multicolumn{4}{|c|}{ Pond water } & \multicolumn{8}{|c|}{ Fish intestine content } \\
\hline & \multirow{2}{*}{ P 1} & \multirow{2}{*}{ P 2} & \multirow{2}{*}{ P 3} & \multirow{2}{*}{ Avg. } & \multicolumn{2}{|c|}{ Pond 1} & \multicolumn{2}{|c|}{ Pond 2} & \multicolumn{2}{|c|}{ Pond 2} & \multicolumn{2}{|c|}{ Average } \\
\hline & & & & & Mean & $\%$ & Mean & $\%$ & Mean & $\%$ & Mean & $\%$ \\
\hline Alonella sp. & 0 & 0 & 1,125 & 375 & 167 & 0.7 & 0 & 0 & 0 & 0 & 56 & 0.3 \\
\hline Amoeba sp. & 0 & 180 & 0 & 60 & 0 & 0 & 0 & 0 & 0 & 0 & 0 & 0 \\
\hline Brachionus sp. & 8,325 & 4,590 & 1,260 & 4,725 & 133 & 0.5 & 0 & 0 & 33 & 0.3 & 56 & 0 \\
\hline Cyclops sp. & 0 & 113 & 0 & 38 & 0 & 0 & 0 & 0 & 0 & 0 & 0 & 0 \\
\hline Daphnia sp. & 0 & 23 & 0 & 8 & 0 & 0 & 0 & 0 & 0 & 0 & 0 & 0 \\
\hline Lecane sp. & 900 & 270 & 0 & 390 & 33 & 0.1 & 33 & 0.3 & 33 & 0.3 & 33 & 0.2 \\
\hline Nauplius & 450 & 293 & 945 & 563 & 0 & 0 & 0 & 0 & 0 & 0 & 0 & 0 \\
\hline \multicolumn{13}{|l|}{$\begin{array}{l}\text { Fitoplankton } \\
\text { (Cell/L) }\end{array}$} \\
\hline Amphipleura sp. & 225 & 0 & 0 & 75 & 67 & 0.3 & 33 & 0.3 & 0 & 0 & 33 & 0.2 \\
\hline Cyclotella $\mathrm{sp}$. & 0 & 0 & 0 & 0 & 4,533 & 19 & 2,300 & 18 & 367 & 3 & 2,400 & 14.6 \\
\hline Clamydomonas sp. & 0 & 0 & 0 & 0 & 2,133 & 8.8 & 600 & 4.7 & 967 & 7.7 & 1,233 & 7.5 \\
\hline Crucigenia sp. & 0 & 0 & 0 & 0 & 3,933 & 16.2 & 3,333 & 26.2 & 2,700 & 21.6 & 3,322 & 20.1 \\
\hline Diadesmis sp. & 0 & 0 & 0 & 0 & 0 & 0 & 0 & 0 & 0 & 0 & 0 & 0 \\
\hline Euglena sp. & 0 & 0 & 0 & 0 & 500 & 2.1 & 233 & 1.8 & 0 & 0 & 244 & 1.5 \\
\hline Gyrosigma sp. & 0 & 0 & 0 & 0 & 0 & 0 & 33 & 0,3 & 0 & 0 & 11 & 0.1 \\
\hline Merismopedia sp. & 0 & 0 & 0 & 0 & 933 & 3.8 & 667 & 5.2 & 467 & 3.7 & 689 & 4.2 \\
\hline Microcystis sp. & 0 & 0 & 0 & 0 & 1,000 & 4.1 & 1,667 & 13.1 & 667 & 5.3 & 1,111 & 6.7 \\
\hline Microspora sp. & 450 & 68 & 68 & 195 & 0 & 0 & 0 & 0 & 0 & 0 & 0 & 0 \\
\hline Navicula sp. & 225 & 0 & 0 & 75 & 167 & 0.7 & 200 & 1.6 & 233 & 1.9 & 200 & 1.2 \\
\hline Nitzschia sp. & 0 & 0 & 0 & 0 & 200 & 0.8 & 700 & 5.5 & 833 & 6.7 & 578 & 3.5 \\
\hline Oocystis sp. & 0 & 0 & 0 & 0 & 0 & 0 & 0 & 0 & 367 & 2,9 & 122 & 0.7 \\
\hline Oscillatoria sp. & 1800 & 135 & 0 & 645 & 800 & 3.3 & 333 & 2.6 & 200 & 1.6 & 444 & 2.7 \\
\hline Phacus sp. & 5,400 & 360 & 0 & 1,920 & 100 & 39.0 & 167 & 17.8 & 133 & 43.5 & 133 & 0.8 \\
\hline Scenedesmus sp. & 0 & 0 & 0 & 0 & 9,467 & 0.4 & 2,267 & 1.0 & 5,433 & 0.5 & 5,722 & 34.7 \\
\hline Straurastrum sp. & 0 & 0 & 0 & 0 & 100 & 0.4 & 133 & 1.3 & 67 & 1.1 & 100 & 0.6 \\
\hline Thalassionema sp. & 450 & 90 & 248 & 263 & 0 & 0 & 0 & 0 & 0 & 0 & 0 & 0 \\
\hline Total & 18,225 & 6,120 & 2,520 & 8,955 & 2,4267 & & 12,700 & & 12,500 & & 16,489 & \\
\hline
\end{tabular}

Milkfish feed was dominated by genera of phytoplankton, which reach more than $99 \%$. The most dominant of phytoplankton was Scenedesmus sp. (34.7\%), then Crucigenia sp. (20.1\%), followed by Cyclotella sp. (14.6\%), Clamydomonas sp. (7.5\%) and next Microcystis sp. $(6.7 \%)$, while the other genera less than $4.2 \%$. The high plankton composition in gut content indicated milkfish utilizing feed available in pond waters. Shrimp pond waste was largely an organic material broken down by microbes into inorganic nutrients, and phytoplankton utilized for its growth.

\section{Discussion}

Growth is the increase in the length or weight of an organism over a period of time, including the process of increasing the volume and number of cells, so size the bodies of the living things grow. Investigation of milkfish reared with feed wastewater of vannamei shrimp pond showed that milkfish could grow well, and hence their length and weight increased during culture period in the shrimp pond wastewater reservoir. Milkfish was able to utilize wastewater from shrimp pond, where the waste majority was consist of natural food and feed residues, and others materials (Nguyen et al., 2007). Wastewater from shrimp culture consisted of a mixture mainly composed of effluent containing high concentrations of nitrogen and phosphorus, and sediment containing uneaten feeds, shrimp excrement and biological remains (Yanfeng et al., 2015), the shrimp waste was helpful for the rapid growth of phytoplankton. 
Milkfish that culture with feed wastewater of vannamei shrimp pond could show good performance in growth, including length-weight relationship, biweekly growth and daily growth rate. Milkfish could grow either in length and weight showing the milkfish got enough of food intake from shrimp wastewater and natural food available in the waters. Wastewater of shrimp pond culture contains about $10 \%$ feed residual, which can be used by milkfish directly or indirectly for feed source. Natural food such as plankton, detritus, and algae were the natural food of milkfish, and essentially needed for milkfish growth. Milkfish is plankton feeder (Rao and Sivani, 1996), the main feed was algae, diatoms and moderate occurrence of detritus indicates. In this study, the main food intake of milkfish was phytoplankton, namely Scenedesmus sp. and Crucigenia sp. accounted for more than $54 \%$ in intestine contents. This finding was slightly different with milkfish in Sermo Reservoir (Djumanto et al., 2017) that the main feed was plankton composed of phytoplankton $52 \%$ and zooplankton $48 \%$, and no detritus found in the digestive tract. In contrast, the main feed of milkfish in Djuanda Reservoir was zooplankton 43\%, and phytoplankton $38 \%$, and water plants leaf $9 \%$ (Aqil et al., 2013; Purnamaningtyas and Tjahjo, 2013). The difference in milkfish feed composition was might cause by the type and abundance of natural feed available in each different waters, so milkfish shall adapt to the type of feed that was present.

The growth of milkfish during culture period reached to $8.2-8.5 \mathrm{~cm}$ and $28.4-29.9 \mathrm{~g}$, meanwhile daily growth rate attained to 0.11 $\mathrm{cm} /$ day and $0.39 \mathrm{~g} /$ day. The daily growth rate was relatively lower compared to the daily growth rate of milkfish culture in poly culture with tiger shrimp and seaweed, i.e. 0.231-0.284 $\mathrm{cm} /$ day and 0.36-0.46 g/day (Guido et al., 2014), however higher than the daily growth rate of milkfish in Sermo Reservoir which ranged $0.0084-0.2056 \mathrm{~cm} /$ day and 0.063-0.118 g/day (Djumanto et al., 2017). The milkfish could utilize waste of shrimp farming as energy source, due to the waste was mainly composed of uneaten feeds, feces, various algae debris and zooplankton remains after it was dried. However, when compared with daily growth rate of milkfish in Djuanda Reservoir reaching 0.72 g/day (Tjahyo and Purnamaningtyas, 2009), then the growth rate of milkfish in the Djuanda Reservoir reached almost doubling. This was possibly caused by the quality and quantity of natural feed available in the Djuanda reservoir was more complete and varied, so as to support the needs of milkfish feed. Milkfish with feed more complete and enough was able to grow better than the less (Rao and Sivani, 1996).

Shrimp farming wastewater consist of organic materials in the form of solids and liquids that can be broken down by microbes into nutrients. The main content of shrimp feed is protein, carbohydrate and fat will be overhauled by bacteria to nitrogen and phosphate. Next nitrogen and phosphate will be utilized by phytoplankton for their growth. One effort to exploit the population of phytoplankton in the pond is to introduce milkfish. Milkfish is a fish whose main feed consists of cyanobacteria, phytoplankton, algae, and detritus (Bagarinao, 1994), so it is suitable for cultivation in shrimp pond wastewater reservoir. Milkfish is an euryhaline fish species that is able to adapt to a wide range of salinity ranging from freshwater, brackish to saline or high salinity (Bagarinao 1994, Nelson et al., 2016) with water salinity range between $0-158 \mathrm{ppt}$, so as to live in freshwater habitat, brackish and salty.

In milkfish pond, dissolved oxygen depletion during this study was caused by increasing of organic material waste and low concentration of phytoplankton. With an increase in deposition of organic material wastewater from shrimp pond, the underlying milkfish pond became enriched with organic matter. Therefore, decomposition of organic matter consumed more oxygen, and low phytoplankton density within milkfish pond lead to reduce oxygen availability in the waters. The main composition of organic wastewater of shrimp feed was a protein that was converted by microbes into ammonia, then ammonia reacts with oxygen to nitrite and nitrate, thereby leading to high total nitrogen concentration in the water. Such high oxygen demand from the organic waste must be one of the most important factors contributing to the lower level of dissolved oxygen in the water of pond wastewater reservoir (Srithongouthai and Tada, 2017). A significant increase in total nitrogen and phosphate concentrations in the milkfish water pond coincided with increasing organic waste disposal from shrimp farm and during high water temperature and low dissolved oxygen levels. Rapid organic matter mineralization in milkfish aquaculture resulted in a significant efflux of ammonium and phosphate (Holmer et al., 2002). 


\section{Acknowledgement}

The authors would like to thank the Faculty of Agriculture UGM who has provided lecturer research grant period 2017. This paper is part of research activities on the development of shrimp ponds in the Village of Keburuhan, subdistrict of Purworejo which was financed from various sources. Thank you to the students who have assisted in sampling fish in the field and observations in the laboratory, as well as all those who have helped from the beginning until the completion of the research. Acknowledgments are also conveyed to the reviewer who has provided constructive suggestions and recommendation for the improvement of this paper.

\section{References}

Aqil, D.I., L.S.E Putri, and Lukman. 2013. Use of plankton as source of fish food in Ir. H. Juanda reservoir, West Java. Al-Kauniyah Jurnal Biologi, 6(1): 13-25.

Bagarinao, T. 1994. Systematics, distribution, genetics and life history of milkfish, Chanos chanos. Environmental Biology of Fishes, 39(1): 23-41.

Biswas, S.P. 1992. Manual of Method in Fish Biology. South Asian Publisher, New Dehli, 112 p.

Djumanto, Ustadi, Rustadi, and B. Triyatmo. 2016. Feasibility study on the profitability of Vannamei shrimp aquaculture on coastal area of Keburuhan Village, Purworejo regency. Aquacultura Indonesiana, 17 (1): 7-11.

Djumanto, B.E. Pranoto, V.S. Diani, and E. Setyobudi. 2017. Food and the growth of introduced milkfish, Chanos chanos (Forsskål, 1775) in Sermo Reservoir, Kulon Progo. Jurnal Iktiologi Indonesia, 17(1): 83-100.

Guido, F.S. Melki, and Isnaini. 2014. Growth rate of tiger shrimp (Penaeus monodon), milkfish (Chanos chanos), and seaweed (Eucheuma cottonii, Gracilaria sp.) on polyculture cultivation with different density in Sungai Lumpur Village of OKI Regency of South Sumatera. Maspari Journal, 6(1): 46-55.

Holmer, M., N. Marba, J. Terrados, C.M. Duarte, and M.D. Fortes. 2002. Impacts of milkfish (Chanos chanos) aquaculture on carbon and nutrient fluxes in the Bolinao area, Philippines. Mar.Pollut.Bull., 44:685-696.

Jhingran, V.G. 1982. Fish and Fisheries of India, 2nd ed. Hindustan Publishing Corporation, New Delhi, India, $954 \mathrm{p}$.

Nelson, J.S., T.C. Grande, M.V.H. Wilson. 2016. Fishes of the World. 5th Ed. John Wiley \& Sons, Inc., Hoboken, New Jersey, 752 p.
Nguyen, V. T., S. Momtaz and K. Zimmerman. 2007. Water pollution concerns in shrimp farming in Vietnam: a case study of Can Gio, Ho Chi Minh City. The International Journal of Environmental, Cultural, Economic and Social Sustainability, 3(2): 129-136.

Purnamaningtyas, S.E. and D.W.H Tjahjo. 2013. Food Habit and Niche Breadth of Some Fish Species at Djuanda Reservoir, West Java. Bawal, 5(3): 151-157.

Ricker, W.E. 1973. Linear regression in fishery research. Journal of the Fisheries Research Board of Canada, 30(3):409-434.

Rao, L.M. and G. Sivani.1996. The food preferences of five commercially important fishes of Gosthani estuary. Indian Journal of Fisheries, 43(2): 199-202.

Srithongouthai, S. and K. Tada. 2017. Impacts of organic waste from a yellowtail cage farm on surface sediment and bottom water in Shido Bay (the Seto Inland Sea, Japan). Aquaculture, 471(1): 140-145.

Stickney, R.R., J.H. Hesby, R.B. McGeachin, and W.A. Isbell. 1979. Growth of Tilapia nilotica in ponds with different histories of organic fertilization. Aquaculture 17:189-194.

Suthers, I.M. and D. Rissik. 2008. Plankton, A Guide To Their Ecology And Monitoring For Water Quality. CSIRO Publishing, Australia, $272 \mathrm{p}$.

Triyatmo, B., D. Suadi, Ambarwati, and Sukardi. 2016. Technical and financial aspects of white shrimp (Litopenaeus vannamei) culture in Coastal Sandy Soil Area of Bantul Regency. Aquacultura Indonesiana, 17(2): 54-59.

Tjahjo, D.W.H. and S.E. Purnamaningtyas. 2009. Evaluation on capability of milkfish and tilapia for using fitoplankton abundance in Ir. $\mathrm{H}$. Djuanda Reservoir. Proceedings of National Competing Forum of Resources Fish II, pp. 1-11.

Yakupitigage, A., P. Edwards, and K.L. Wee. 1991. Supplementary feeding of fish in a duck-fish integrated system. I. The effect of rice-bran. In: Silva, S.S.D. (Ed.), Fish Nutrition Research in Asia. Proceedings of the Fourth Asian Fish Nutrition Workshop. Asian Fish, Soc. Spec. Publ. 5. Asian Fisheries Society, Manila, Philippines, pp. 143-157.

Yanfeng, C., L. Peng, HU Chaoqun, and R. Chunhua. 2015. Effect of shrimp (Litopenaeus vannamei) farming waste on the growth, digestion, ammonium-nitrogen excretion of sea cucumber (Stichopus monotuberculatus). Journal of Ocean University of China, 14(1): 484-490.

Yuan D., Y. Yi, A. Yakupitiyage, K. Fitzimmons, and J.S. Diana. 2010. Effects of addition of red tilapia (Oreochromis spp.) at different densities and sizes on production, water quality and nutrient recovery of intensive culture of white shrimp (Litopenaeus vannamei) in cement tanks. Aquaculture, 298 (2): 226-238. 